\title{
The E-3 Test Facility at Stennis Space Center: Research and Development Testing for Cryogenic and Storable Propellant Combustion Systems
}

\author{
John T. Pazos ${ }^{1}$, Craig A. Chandler ${ }^{2}$, and Nickey G. Raines ${ }^{3}$ \\ National Aeronautics and Space Administration, John C. Stennis Space Center, MS 39529
}

\begin{abstract}
This paper will provide the reader a broad overview of the current upgraded capabilities of NASA's John C. Stennis Space Center E-3 Test Facility to perform testing for rocket engine combustion systems and components using liquid and gaseous oxygen, gaseous and liquid methane, gaseous hydrogen, hydrocarbon based fuels, hydrogen peroxide, high pressure water and various inert fluids. Details of propellant system capabilities will be highlighted as well as their application to recent test programs and accomplishments. Data acquisition and control, test monitoring, systems engineering and test processes will be discussed as part of the total capability of $E-3$ to provide affordable alternatives for subscale to full scale testing for many different requirements in the propulsion community.
\end{abstract}

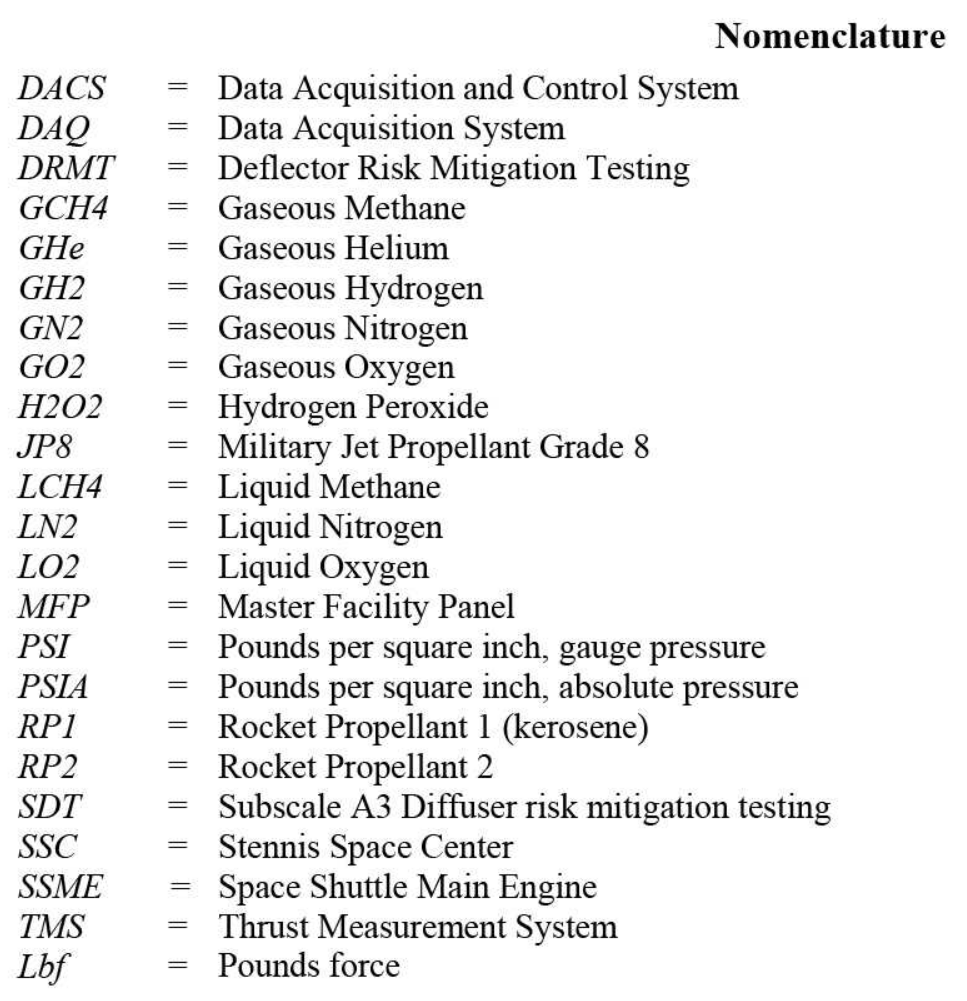

\section{Introduction}

Stennis Space Center is a fully capable test laboratory with capability on the A and B Test Stands to test articles as large as the Saturn V first stage booster and down to a Space Shuttle Main Engine, the XRS-2200 Linear

\footnotetext{
${ }^{1}$ Mechanical Design Engineer, Engineering and Test Directorate, Stennis Space Center, MS

${ }^{2}$ Test Director, E-2/E-3 Facilities, Engineering and Test Directorate, Stennis Space Center, MS

${ }^{3}$ Former Deputy Chief Engineer, Engineering and Test Directorate, Stennis Space Center, MS
} 
Aerospike, or the J2X Powerpack. The E-Complex is intended for research and development of components, propulsion system elements and complete propulsion systems and engines. Stennis maintains a High Pressure Gas Facility to keep the 20 miles of distributed underground piping supplied with hydrogen, nitrogen, helium, and missile grade air. A High Pressure Industrial Water system supplies cooling water to the Test Stands with backup diesel power generators to help maintain Test Stand integrity. The Cryogenic Storage and Transfer Facility maintains a fleet of cryogenic barges to move propellant to the A and B Test Stands. At the Fluid Component Processing Facility, valves are rebuilt and cleaned and piping and tubing are tested and cleaned for precision service. The onsite weld shops, machine shops, and carpenter shops can provide fabrication support for the entire test center, including test article parts. Procurement, receiving, secure storage, and warehousing are all provided.

Professional engineering support includes Systems, Operations, Design, and Analysis divisions. Systems provides the engineering management necessary to ensure that the test facilities and the systems' design safely fulfill the test requirements of the customer's test programs. The E-3 Test Stand Operations group consists of engineering and technical personnel to process and install test articles, conduct tests, and remove test articles. They will configure the test facilities, control systems, instrumentation, and data acquisition systems for test firings. The Design and Analysis group provides electrical and mechanical engineering design and analytical services in direct support of testing activities. These services include, but are not limited to the following: preliminary test requirements analysis; test facility capability improvement efforts and cost estimates; test article to test stand interface analysis; test operations support for independent test analysis and evaluation.

\section{Facility Modeling Rocket Propulsion Test Analysis Model}

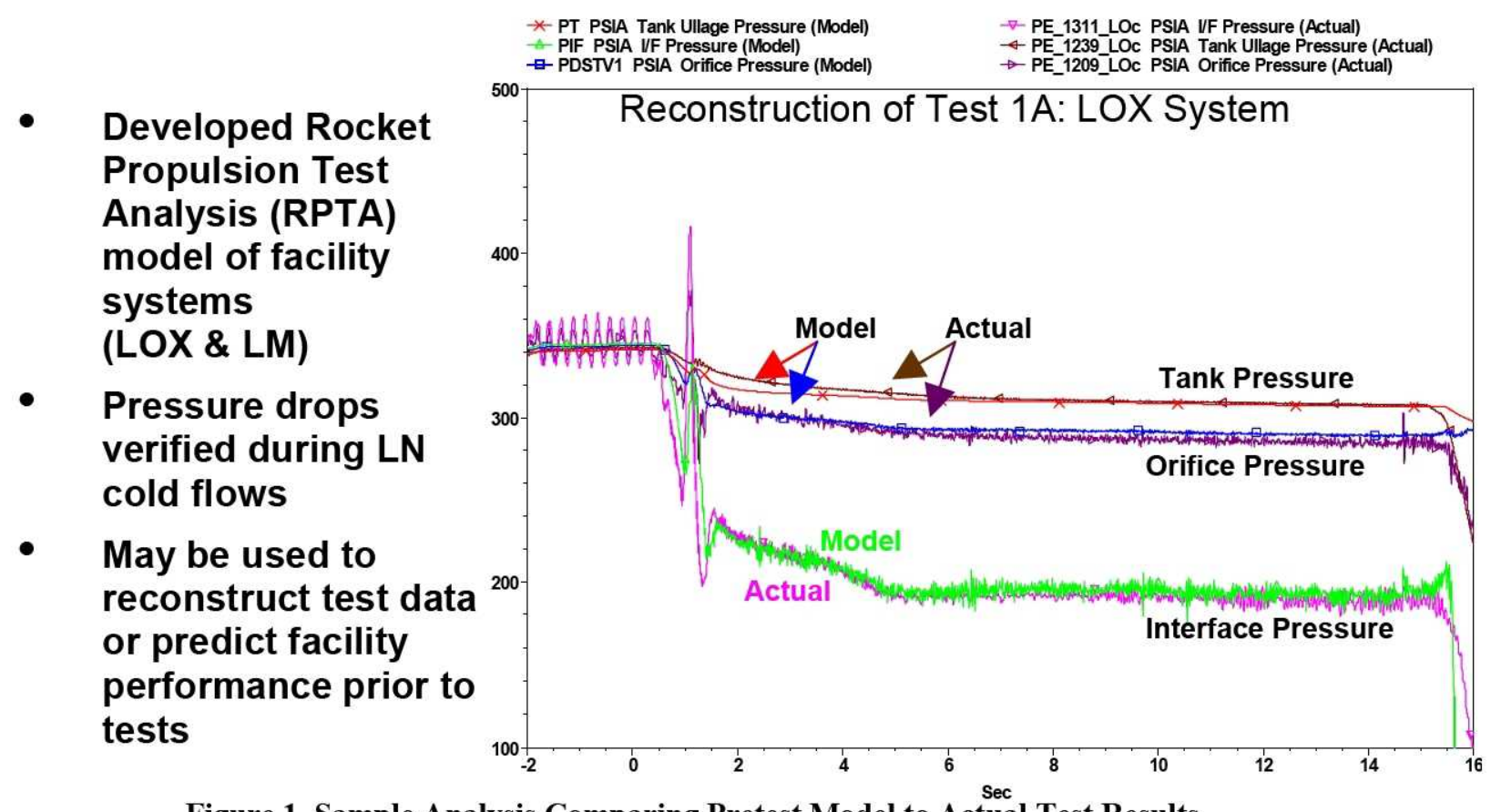

Figure 1. Sample Analysis Comparing Pretest Model to Actual Test Results.

\section{E-3 Test Facility}

The E-3 Test Facility is a versatile test complex available for component development testing of combustion devises, rocket engine components, and small/subscale complete engines and boosters. The facility currently has two cells. Cell 1 has a horizontal position which can support thrust loads up to 60,000 lbf. Cell 1 also has a vertical position with simulated altitude capability for small combustors up to 1,000 lbf. Altitude is provided by steam driven ejectors utilizing the Cell 2 steam generator capability. Cell 2 is primarily for vertical testing with provisions 
for some horizontal tests. Cell 2 can support vertical loads up to $25,000 \mathrm{lbf}$ above the flame bucket and horizontal loads up to $20,000 \mathrm{lbf}$ thrust. The physical layout can be seen below in Fig. 2.

The facility has the capacity to deliver propellants at low and medium pressures, up to $3,000 \mathrm{psi}$. All propellant storage, transfer, and run systems for $\mathrm{LO} 2$ and $\mathrm{GO} 2$ are cleaned to Stennis standards for $\mathrm{LO} 2 / \mathrm{GO} 2$ systems to eliminate the possibility of contamination induced malfunctions or fires. Similar systems for $\mathrm{H} 2 \mathrm{O} 2$ are cleaned to the same specification as the LO2 system and then passivated with increasing concentrations for $\mathrm{H} 2 \mathrm{O} 2$ before service. The RP/JP propellant systems are maintained clean using a series of filters and oil/water separators and coalescers. All gases are delivered from the site wide systems and are kept at the clean levels required for the SSME and RS68 test programs.

Single axis thrust measurement capability is available for both Cell 1 and Cell 2 with systems for $10 \mathrm{~K}, 25 \mathrm{~K}$, and $60 \mathrm{~K}$ test articles. All systems in both cells can be made available to work together increasing capability for a single program or allowing for multiple test article, multiple program activity. All cells are illuminated for night time work and for high speed video capture. Cell 1 has a 5 ton bridge crane for lifting test articles and facility hardware. Customer bays are available for test article work at the test facility or in the test support building.

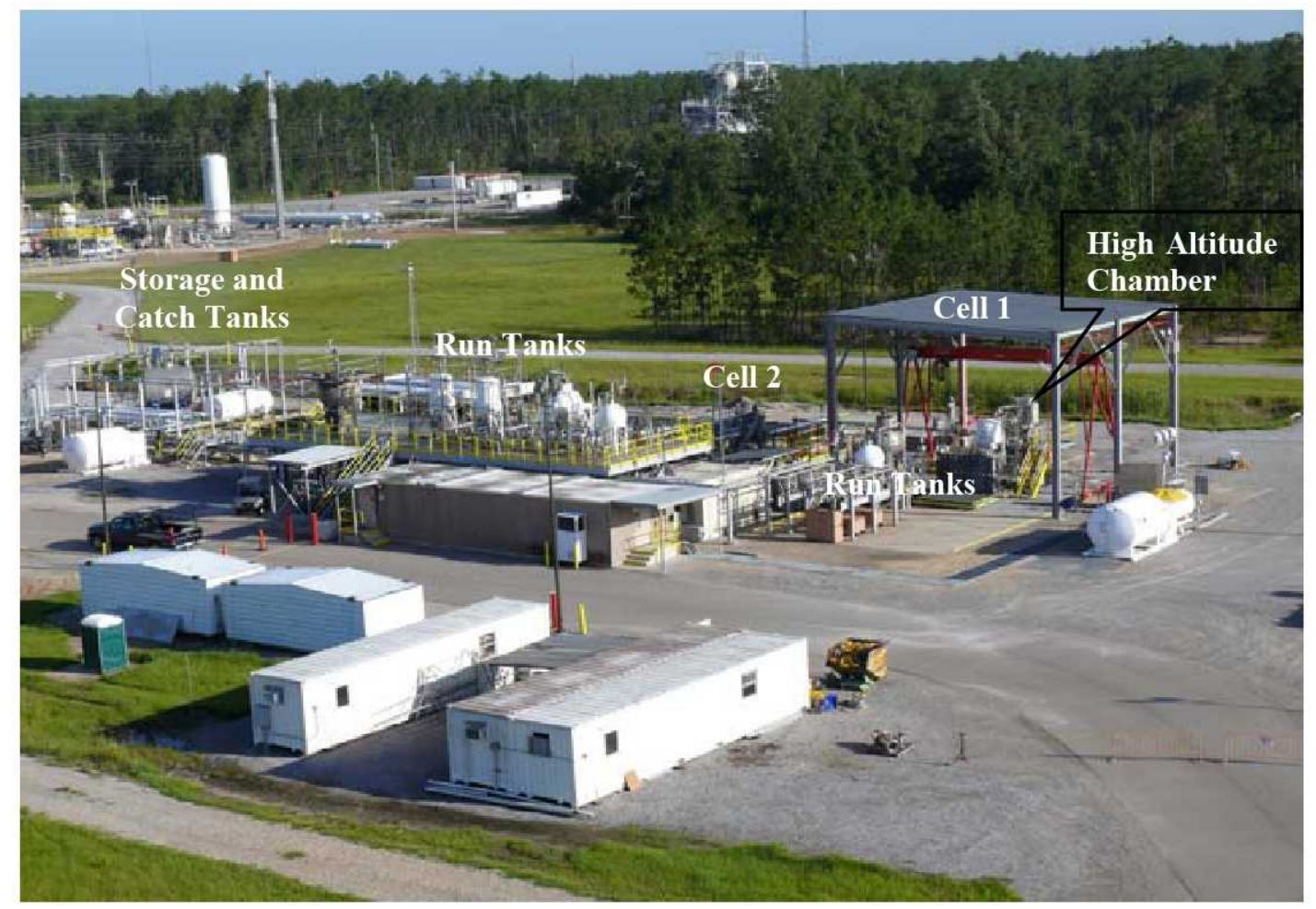

Figure 2. E-3 Cell 1 and Cell 2 Physical Layout.

E-3 began as the Diagnostics Testbed Facility in 1988 and has undergone several different reincarnations to reach its current facility configuration. Successful testing has continued non-stop for the past 20 years. Various test articles and fuels have been part of the E-3 history. Oxygen-fed hybrid rockets, including a flight demonstration hybrid sounding rocket were developed and tested at E-3. Successful $\mathrm{H} 2 \mathrm{O} 2$ tests included the AR2-3 engine and the Boeing Rocketdyne Hypergolic Injector (BRHI). Methane has been used both as cryogenic liquid for the Advent engine and as gas for several experimental combustors. Hydrocarbon fuels have been used on many programs including TGV and AR2-3. Gaseous hydrogen has been the propellant of choice for the J2X simulator and the Steam Generator. Figure 3 shows the high altitude (low pressure) test chamber and subscale rocket engine setup. Figure 4 shows the camera view looking downstream while test firing. The flame can be seen at end of the chamber. Figure 5 shows a hybrid rocket being tested at E-3 Cell 2. 


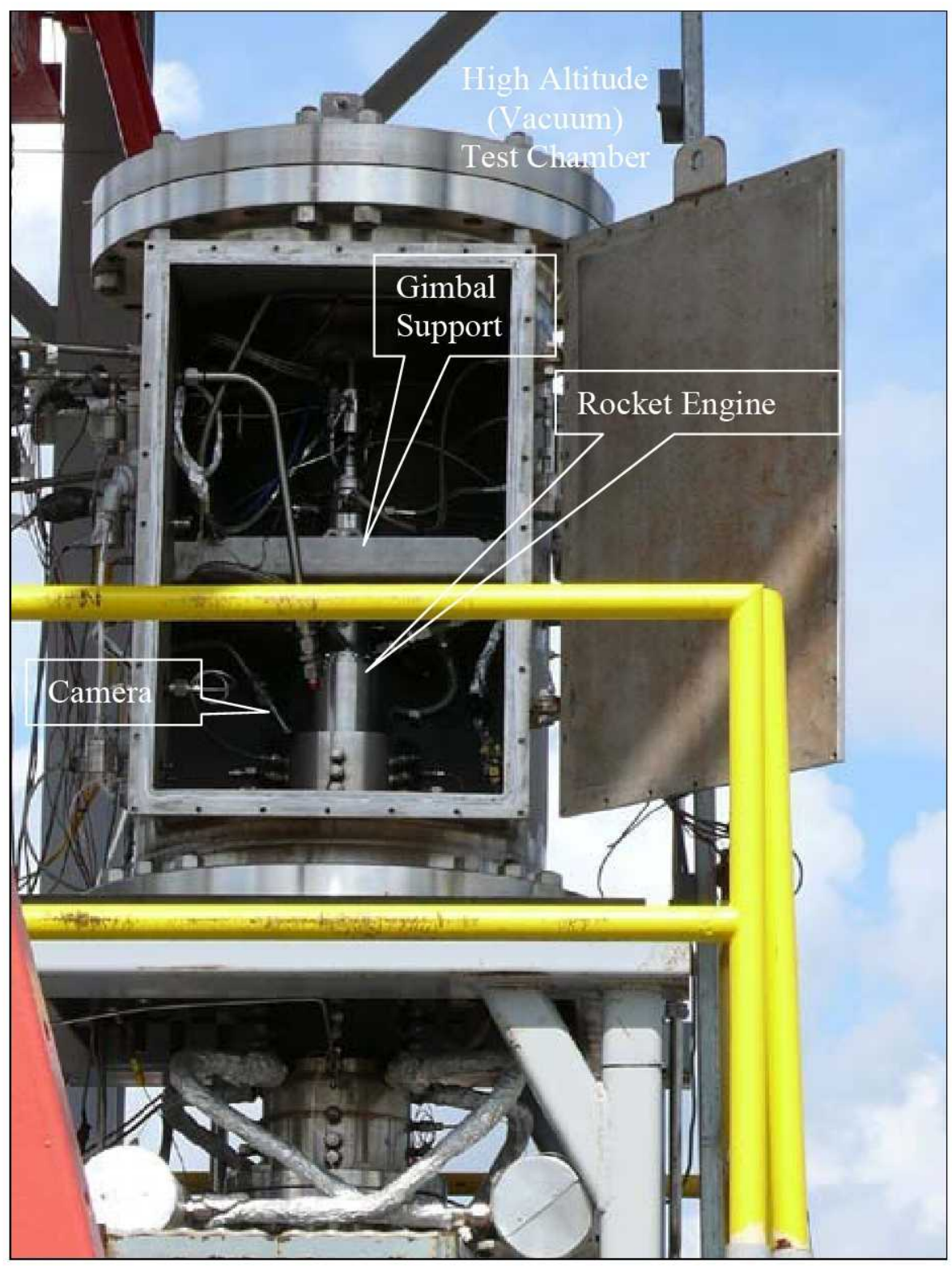

Figure 3. High Altitude Chamber at E-3 Cell 2. 


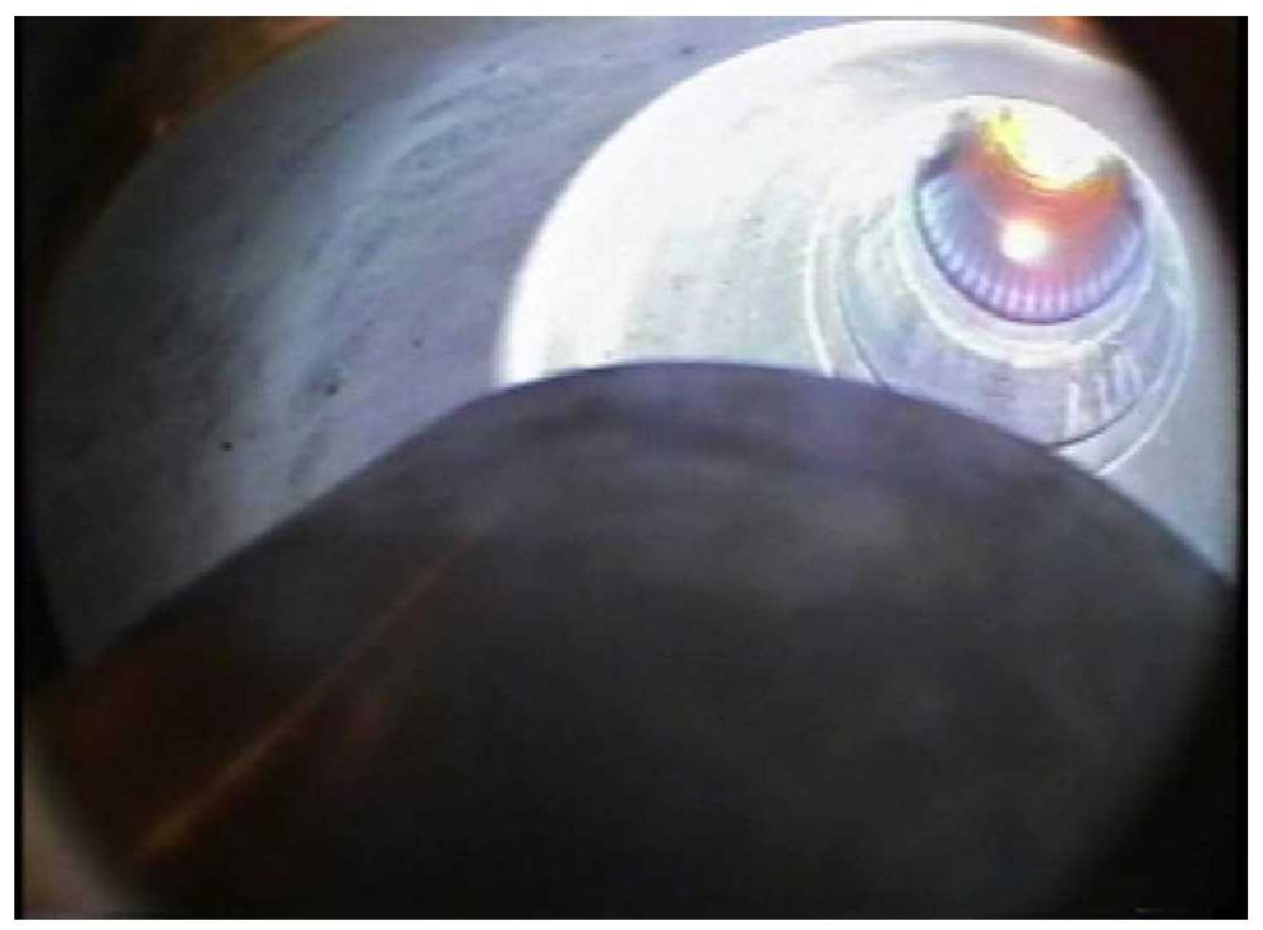

Figure 4. View of Combustion Chamber During Test Firing on SDT.

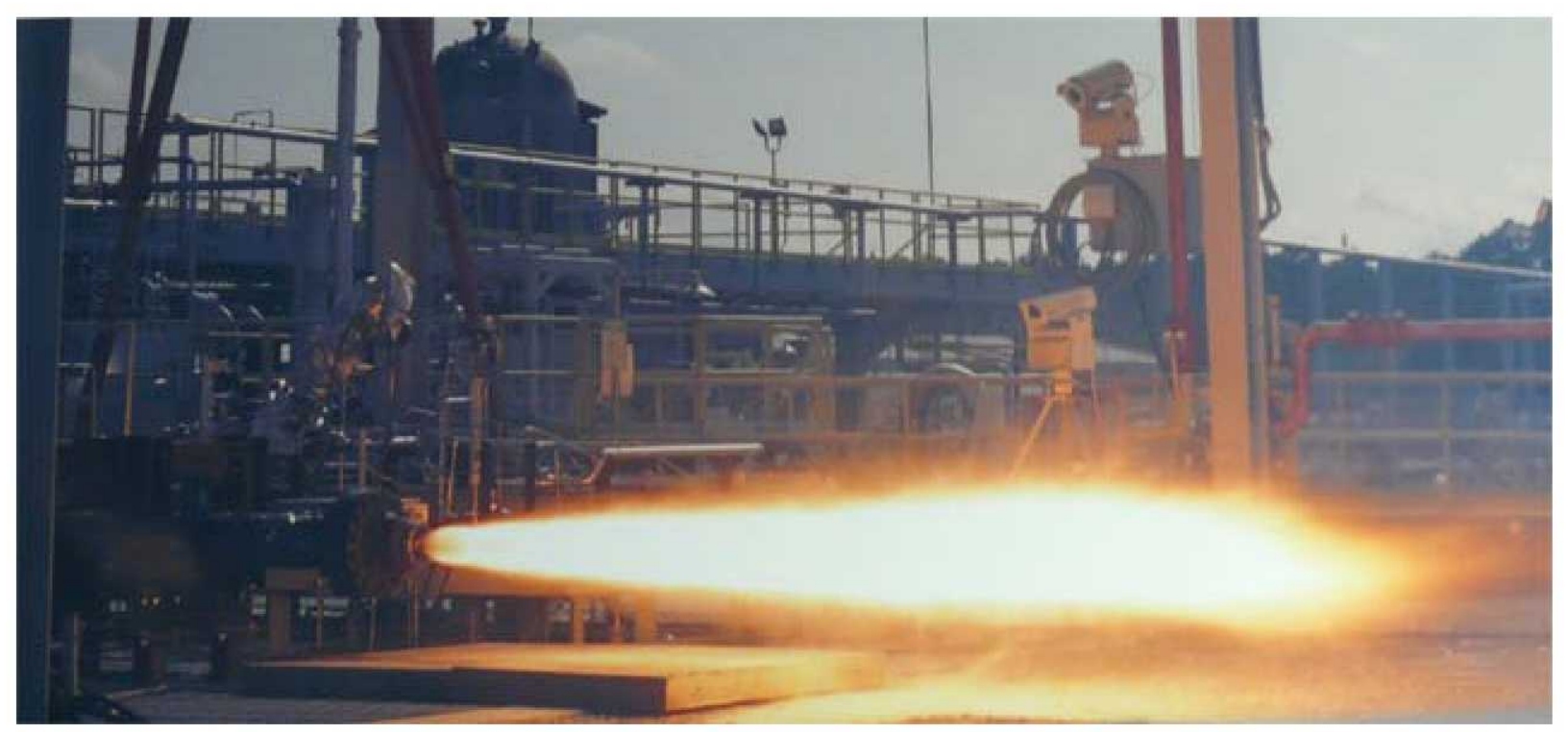

Figure 5. Oxygen-fed Hybrid Rocket Test - 2005 .

\section{Capabilities}

The physical layout of the E-3 test cells and the various propellant systems can be seen in Fig. 2. Discussion of the systems, the size of storage and run tanks and maximum flow rate capabilities are listed below.

\section{A. Liquid Oxygen}

The LO2 is stored in a 2,000 gallon horizontal vessel and transferred to any of the run tanks. GN from the site wide system is used to pressurize the storage and run tanks. Run tanks can deliver up to $112 \mathrm{lbm} / \mathrm{s}$ of LO2 to the test cells. In addition to the current $\mathrm{LO} 2$ capabilities, construction operations are underway to upgrade the storage 
system with a new 11,000 gallon storage tank and pressure build coil. Various devices are used for LO2 flow measurement.

\section{B. Liquid Methane}

The LCH4 is stored in a 2,000 gallon horizontal vessel and transferred to the run tank. Site wide system GN is used to pressurize the tanks. Various devices are used for LCH4 flow measurement. All methane vapors are burned in the facility flare stack.

\section{RP-1/JP-8 Hydrocarbon Fuels}

Hydrocarbon fuels are stored in various vessels or tanker trucks and transferred to the run tanks at Cell 1 and Cell 2 as required. The site wide GN system is used to pressurize the tanks. A maximum of $40 \mathrm{lbm} / \mathrm{s}$ can be delivered to the test cells. Various devices are used for flow measurement. Environmental rules are strictly followed including monitoring of exhaust plumes for air permits and monitoring all releases to the ground for impact to ground water.

\section{Gaseous Hydrogen}

The GH2 is stored in two large tube bank trailers and replenished from the site wide GH2 system. It is available at a maximum pressure of $2,900 \mathrm{psi}$. It is transferred directly to the test article from the tube trailers.

\section{E. Hydrogen Peroxide}

The $\mathrm{H} 2 \mathrm{O} 2$ is stored in two tanks and transferred to the run tanks at Cell 1 and Cell 2 as required. The site wide GN system is used to pressurize the tanks, delivering up to 112 $\mathrm{lbm} / \mathrm{s}$ to the test cells. Liquid $\mathrm{H} 2 \mathrm{O} 2$ discharges from both test cells are routed to a 4,500 gallon catch tank and then sent through a catalyst bed for decomposition. The Cell 2 flame bucket is used as an emergency catch tack if the $\mathrm{H} 2 \mathrm{O} 2$ has to be dumped from the run tanks and/or run system during testing. The $\mathrm{H} 2 \mathrm{O} 2$ is then pumped from the flame bucket to a 100,000 gallon concrete containment basin to reduce the

\begin{tabular}{|c|c|c|}
\hline $\begin{array}{c}\text { Vessel } \\
\text { Commodity }\end{array}$ & $\begin{array}{c}\text { MAWP } \\
\text { (psig) }\end{array}$ & Volume \\
\hline \multicolumn{3}{|c|}{ Propellant Storage/Dump Tanks } \\
\hline LOX & 60 & 600 gallon \\
\hline LOX & 2,000 & 100 gallon \\
\hline $\mathrm{H} 2 \mathrm{O} 2$ & ATM & 3,500 gallon \\
\hline $\mathrm{H} 2 \mathrm{O} 2$ & ATM & 4,000 gallon \\
\hline $\mathrm{H} 2 \mathrm{O} 2$ & ATM & 4,500 gallon \\
\hline JP-8 & ATM & 3,000 gallon \\
\hline DI Water Storage & ATM & 2,800 gallon \\
\hline LOX & 150 & 11,000 gallon \\
\hline LOX & 60 & 2,000 gallon \\
\hline \multicolumn{3}{|c|}{ Propellant Run Tanks } \\
\hline JP-8 & 3,500 & 250 gallon \\
\hline $\mathrm{H} 2 \mathrm{O} 2 / \mathrm{LOX} / \mathrm{PW}$ & 3,500 & 500 gallon \\
\hline $\mathrm{H} 2 \mathrm{O} 2 / \mathrm{LOX} / \mathrm{PW}$ & 3,000 & 500 gallon \\
\hline JP-8/IPA & 3,500 & 250 gallon \\
\hline JP-8/PW & 3,500 & 1,000 gallon \\
\hline LCH4 & 775 & 250 gallon \\
\hline LOX & 775 & 250 gallon \\
\hline \multicolumn{3}{|c|}{ Pressurization Vessels } \\
\hline $\mathrm{GN} 2 / \mathrm{GHe}$ & 4,500 & $21.7 \mathrm{ft}^{3}$ \\
\hline GN2/GHe & 4,500 & $21.7 \mathrm{ft}^{3}$ \\
\hline GN2/GHe & 4,500 & $21.7 \mathrm{ft}^{3}$ \\
\hline $\mathrm{GN} 2 / \mathrm{GHe}$ & 4,500 & $21.7 \mathrm{ft}^{3}$ \\
\hline GN2/GHe & 4,500 & $21.7 \mathrm{ft}^{3}$ \\
\hline GN2/GHe & 4,500 & $21.7 \mathrm{ft}^{3}$ \\
\hline $\mathrm{GN} 2 / \mathrm{GHe}$ & 4,500 & $21.7 \mathrm{ft}^{3}$ \\
\hline
\end{tabular}
concentration of the fluid prior to disposal.

\section{F. Ancillary Systems}

Some other E-3 Test Stand capabilities provided are as follows:

\section{Flame Deflector - Plume Impingement Area}

Plume impingement areas are provided for both Cell 1 and Cell 2. The areas feature thrust deflectors that are made of refractory concrete ablative material for the purpose of minimizing the effects of heat and acoustic loads generated by a combustion device plume. The material has excellent thermal properties for high temperature applications.

\section{Hydraulic System}

A hydraulic system capable of producing $3,000 \mathrm{psi}$ is available for actuating facility, special test equipment, or test article hydraulic valves.

\section{Deluge System}

The facility has a 4,000 gpm @ 150 psi water deluge system for the purpose of limiting damage in the event of a test stand fire. This system is feed through the E-Complex deluge pumps and covers all test cells, oxidizer and fuel vessels, Cell 2 flame bucket, the containment tank, and all tanker fill headers. Two water cannons are also situated between Cell 1 and Cell 2. 


\section{Methane/Hydrogen Gas Monitoring}

The facility employs a gas detection system with display in the Test Control Center (TCC) that is independent of the facility and test article control system. This detection system provides operators within the TCC visibility into the location of the gas leaks.

5. DI Water Supply System

A Deionized Water System is available that can convert potable water to deionized water. The DI water is stored in a 2,800 gallon tank.

\section{Data Acquisition and Control Systems}

The following is a discussion of the Data Acquisition and Control System capability at E-3. All systems are modern and recently upgraded. Each system is modular and can be easily reconfigured for new test programs as needed. There is a purposeful commonalty of E-Complex hardware so additional channels for E-3 can be provided by loan from E-1 and E-2 Test Stands.

\section{A. Low Speed Data Acquisition System}

Low speed data on E-3 is normally acquired at 250 samples per second during testing. The most common rate for Standby Mode is 1 sample per second, but any number of samples per second can be taken during Test Setup and Monitoring Modes. The system is digital and modular; it is based on Tustin and Pacific hardware. Customized software has been developed to provide for in-place calibration of instrumentation, test day calibration of wet systems, measurement system analysis for uncertainty, etc. Typically, 120 channels of low speed data are available at E-3, split between the two cells. Normal instruments include Stellar and Teledyne strain gauge type pressure transducers, RTDs, various types of thermocouples, and various transmitters for flow and pressure.

\section{B. Control System}

The control system is PLC based and has a sequencer program developed on primary time based control logic with limited capability for event based logic. The sequencer is programmable and is jointly developed with the test article customers. Test day Facility Readiness Tests (FRTs) are performed to ensure that the sequencer program is correctly set up to run the desired test. Graphical user interfaces provide real time readout of data and control settings and allow for in-test monitoring and control including observer red line cuts. Figures 7 and 8 illustrate typical screen views for E-3 testing using Wonder Ware ${ }^{\mathrm{TM}}$.

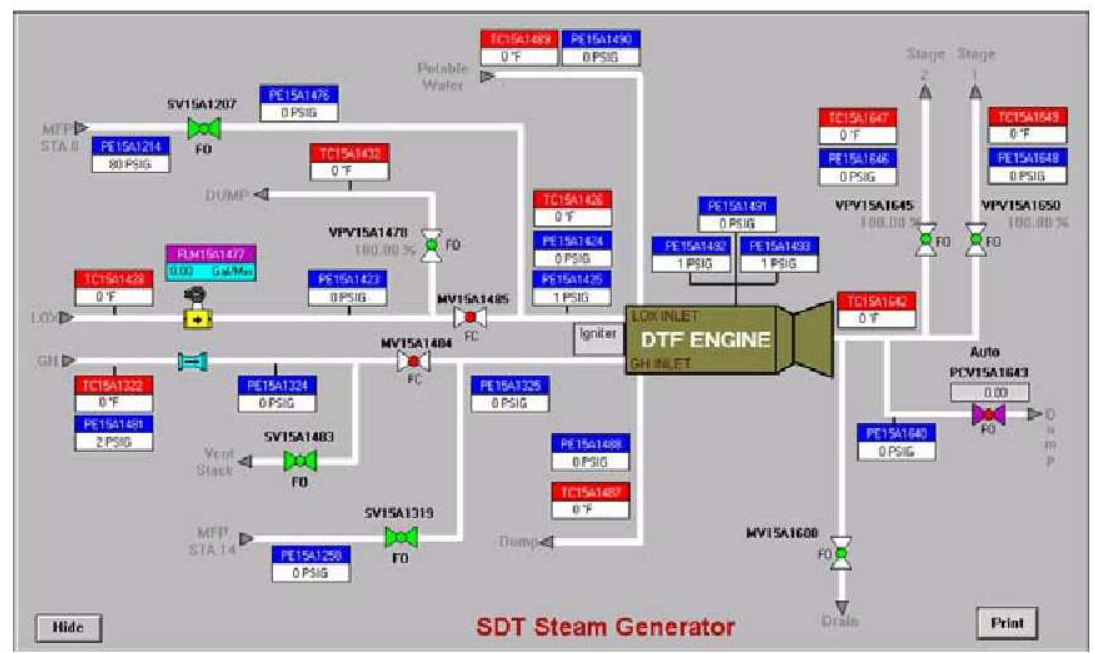

Figure 7. Cell 2 Steam Generator Data Readout and Control Screen. 


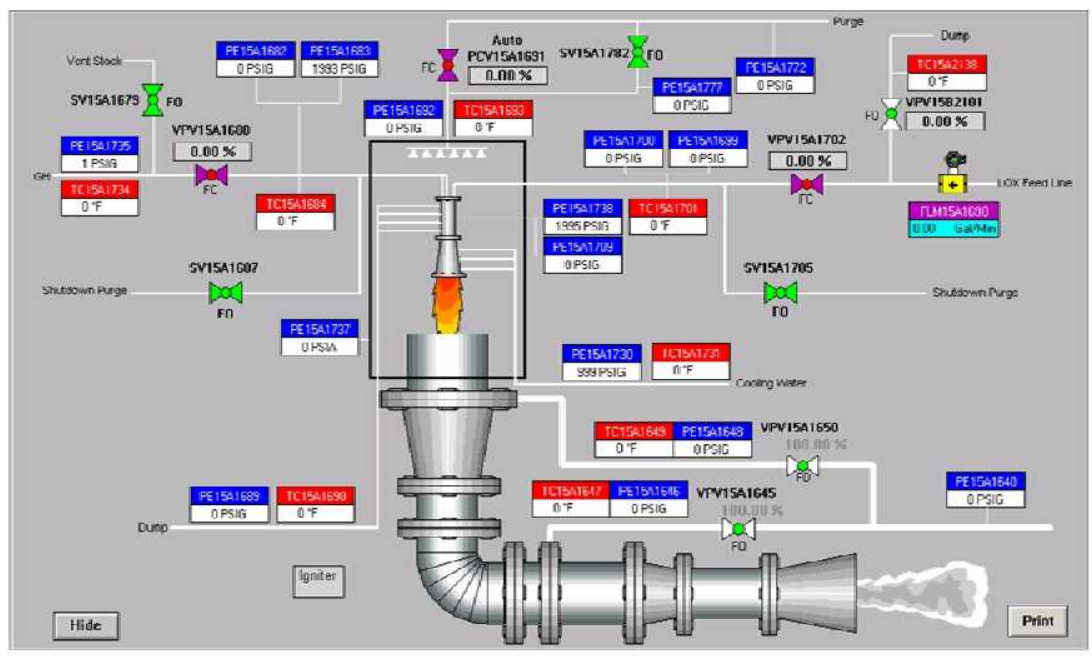

Figure 8. Cell 1 Subscale High Altitude Diffuser Data Readout and Control Screen.

\section{Video System}

Standard low speed color video is available for test recording. High speed color video is also available at a rate of 500 frames per second. Both ultraviolet and infrared filtered cameras and imagers are available as a test service should the customer require. The cameras have pan, tilt, and zoom capability.

\section{Conclusion}

The E-3 Test Stand has continued to evolve and expand its capabilities over the last 20 years in order to keep up with the needs of Stennis' customers. The flexibility of the systems and the variety of propellants available make it a very versatile test facility. Combined with the modern data acquisition and controls systems, this test stand is ready to play an important role in the advancement of space propulsion programs.

\section{Acknowledgments}

The authors wish to acknowledge the work of their engineering and test operations colleagues at SSC's Engineering and Test Directorate and the equally valuable support provided by their contractors.

\section{References}

New Business Development Office, "Test Facilities Capability Handbook, Fourth Edition, Rev 1," John C. Stennis Space Center, November 2001.

Jacks, T.E., Beisler, M.A., "Expanding Hydrogen Peroxide Propulsion Test Capability at NASA's Stennis Space Center EComplex," AIAA 2003-5041, 2003. 